\title{
A practical soil management to improve soil quality by applying mineral organic fertilizer
}

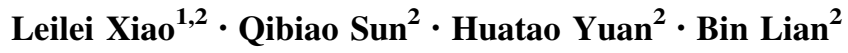

Received: 14 November 2016/Revised: 19 December 2016/ Accepted: 8 January 2017/Published online: 23 January 2017

(C) Science Press, Institute of Geochemistry, CAS and Springer-Verlag Berlin Heidelberg 2017

\begin{abstract}
Heavy use of chemical fertilizer causes increasing soil and environmental crisis, and the use of organic fertilizer increases obvious in recent years. In this study, mineral organic fertilizer (MOF) and compound fertilizer (CF) were applied in amaranth culture to explore the effects of these two kinds of fertilizers on soil quality and the potential function for $\mathrm{CO}_{2}$ fixation. Some soil parameters were tested, e.g. $\mathrm{pH}$ value, organic carbon content, microbial biomass, urease activity, and available potassium content. In addition, some parameters of soil infiltration water were also determined, such as $\mathrm{pH}$ and $\mathrm{HCO}_{3}{ }^{-}$concentration. Experimental results showed that MOF improved soil quality and amaranth biomass and increased possible soil carbon sink. On the contrary, the utilization of CF worsened soil quality and made the soil acidize. These results suggested that MOF can partially replace $\mathrm{CF}$ to improve plant growth, soil quality and possible $\mathrm{CO}_{2}$ sink.
\end{abstract}

Keywords Fertilizer management $\cdot$ Mineral organic fertilizer $\cdot$ Soil quality $\cdot$ Natural way $\cdot$ Carbon fixation

Electronic supplementary material The online version of this article (doi:10.1007/s11631-017-0139-5) contains supplementary material, which is available to authorized users.

Bin Lian

bin2368@vip.163.com

1 Key Laboratory of Coastal Biology and Utilization, Yantai Institute of Coastal Zone Research, Chinese Academy of Sciences, Yantai 264003, China

2 Jiangsu Key Laboratory for Microbes and Functional Genomics, Jiangsu Engineering and Technology Research Center for Microbiology, College of Life Sciences, Nanjing Normal University, Nanjing 210023, China

\section{Introduction}

It is widely accepted that the excessive use of chemical fertilizer (CF) have led to harden and acidify soil. Application of organic fertilizer has been proved to improve soil quality and it is beneficial for the crop growth (Kang et al. 2016). Considering the close correlation between atmospheric $\mathrm{CO}_{2}$ concentration and the large-scale agricultural land use, the investigation that what kinds of fertilizer practices are feasible and effective in blocking the trend of increasing atmosphere greenhouse gas concentrations attracts more and more attention (Liping and Erda 2001; Dhadli and Brar 2016). Large quantities of carbon are exuded through plant root in the form of organic matter and degraded to gaseous form, which will return to the atmosphere ultimately (Ryan et al. 2001). It is the dominant carbon flux, which transports approximately $120 \mathrm{Gt}$ carbon $\mathrm{a}^{-1}$, in the global carbon cycle and is responsible for transporting 20 times the quantity of anthropogenic emissions each year (Renforth et al. 2009). Therefore, soil carbon sink is very important for atmospheric $\mathrm{CO}_{2}$ cycle.

Increased sequestration of carbon in agricultural soils can potentially mitigate the greenhouse effect (Young 2003). Previous studies showed that mineral weathering can stimulate $\mathrm{CO}_{2}$ sink (Schuiling 2014; Xiao et al. 2014, 2015). However, soil carbon sequestration through the practice of agriculture is something that we should value (Lal 2004a), and reasonable agricultural activities may be valuable for the sustainable use of soil and slowing down $\mathrm{CO}_{2}$ release. Agricultural operations affect the carbon cycle mainly through uptake, fixation, emission and transfer of carbon among different pools (Lal 2004b). Manipulation of agricultural land developed great potential to increase soil carbon stocks (Coutinho et al. 2015). It was achievable by 
adopting appropriate agricultural management practices, such as application of fertilizers or organic amendments, conservation tillage and crop rotation (Lal 2004a). At present, chemical fertilizers are to use in large doses, but longterm application of inorganic fertilizers are inadequate to maintain soil organic carbon (SOC) levels and nutrients if no aboveground crop residues return to the soil ( $\mathrm{Su}$ et al. 2006). Recommended management practices are integrated nutrient management with compost, biosolids and nutrient cycling. In general, the SOC pool will be enhanced greater by the use of organic manures and compost than the application of inorganic fertilizers with the same amount of nutrients. Triberti et al. (2008) confirmed the valuable efficacy of manure in increasing both SOC content and soil fertility in the long-term. Recently, manure is applied to increase carbon sequestration in many kinds of soils (Fan et al. 2014; Mahmoodabadi and Heydarpour 2014). However, Schlesinger (1999) pointed out that manure is not likely to yield a net sink for carbon. Unpleasantly, those operations even accelerated $\mathrm{CO}_{2}$ release (Rochette and Gregorich 1998). Schuiling and Andrade (1999) proposed that mixing the fines from olivine mining with a slow-release fertilizer like struvite in the right proportion was a promising solution to the recovery of phosphate with the formation of carbon sink. Other possible mitigation strategies included the use of organic manures and slow-release mineral fertilizers (Metz 2001). However, the related studies are relatively lacking. Seeking such useful and cost-effective ways is very meaningful, although it is long and arduous process.

Potassium is one of the three major plant nutrient elements and plays a pivotal role in agricultural production. Most soils in southern China are deficient in $\mathrm{K}$ (Xie 1998). Fortunately, Potassium-bearing mineral deposit is very rich in China, but direct absorption of potassium in its feldspathic or other silicate forms is impossible for plants (Sun et al. 2013). Amaranth is a common vegetable that is planted widely in China and has a strong ability to enrich $\mathrm{K}$ ions ( $\mathrm{Li}$ et al. 2006). Therefore, this kind of plant was used in this study. The aim of the research reported here is to investigate if the application of mineral organic fertilizer (MOF) can improve the quality of the soil, promote amaranth growth, and meanwhile accelerate the possible fixation of $\mathrm{CO}_{2}$ from atmosphere or soil respiration.

\section{Materials and methods}

\subsection{Mineral organic fertilizer and compound fertilizer}

Mineral organic fertilizer (MOF) was made in a bio-organic fertilizer Ltd. in Puding, Guizhou Province, China.
Corn and sorghum straw and chicken manure were the organic matters, which were mixed with K-bearing silicate mineral power ( 80 mesh) at a ratio of $3: 1$ as the matrix. One $\mathrm{kg}$ microbial fermentation agents, which contained photosynthetic bacteria, Lactobacillus, yeast, Bacillus, Acetobacter, Bifidobacterium and Actinomycetes, was added into 10 ton matrix, followed by fermentation and turning. This process lasted about 30 days. The percentage of organic content was about $34 \%$. The content of $\mathrm{N}, \mathrm{P}_{2} \mathrm{O}_{5}$, and $\mathrm{K}_{2} \mathrm{O}$ in $\mathrm{MOF}$ is $1.9 \%: 1.9 \%: 2.5 \%$. $\mathrm{pH}$ was obvious alkaline about 8.48 . Two kinds of compound fertilizer $(\mathrm{CF})$ were selected. The proportion of $\mathrm{N}$, $\mathrm{P}_{2} \mathrm{O}_{5}$, and $\mathrm{K}_{2} \mathrm{O}$ in one kind of $\mathrm{CF}$ is $15 \%: 15 \%: 15 \%$. The proportion of $\mathrm{N}, \mathrm{P}_{2} \mathrm{O}_{5}$, and $\mathrm{K}_{2} \mathrm{O}$ in another $\mathrm{CF}$ is $11 \%: 11 \%: 18 \%$. In order to make the proportion of $\mathrm{N}$, $\mathrm{P}_{2} \mathrm{O}_{5}$, and $\mathrm{K}_{2} \mathrm{O}$ in $\mathrm{CF}$ be consistent with that of MOF, two kinds of $\mathrm{CF}$ were mixed in the ratio of $1: 1.343$ in the study. The content of $\mathrm{N}, \mathrm{P}$, and $\mathrm{K}$ in $50 \mathrm{~g} \mathrm{MOF}$ is equal to that in $7.476 \mathrm{~g} \mathrm{CF}$. The experiment with no fertilizer treatment was named as WF in this study.

\subsection{Summary of experimental operation}

XRD results showed that soil was composed of quartz $\left(\mathrm{SiO}_{2}\right)$, muscovite $\left(\mathrm{KAl}_{2}\left(\mathrm{Si}_{3} \mathrm{Al}\right) \mathrm{O}_{10}(\mathrm{OH}, \mathrm{F})_{2}\right)$, albite $\left(\mathrm{Na}\left(\mathrm{Si}_{3} \mathrm{Al}\right) \mathrm{O}_{8}\right)$, orthoclase $\left(\mathrm{KAlSi}_{3} \mathrm{O}_{8}\right)$, and kaolinite-1A $\left(\mathrm{Al}_{2} \mathrm{Si}_{2} \mathrm{O}_{5}(\mathrm{OH})_{4}\right)$. Each device (supplemental materials) contained $2000 \mathrm{~g}$ soil and different amounts of fertilizer listed in Table 1. To increase the permeability of soil, $450 \mathrm{~g}$ glass bead was added to those devices. The amaranth was watered timely according to the soil moisture. Water $(500 \mathrm{ml})$ was regularly added to the device every 6 days, and the soil infiltration water (SIW) collected the next day.

\subsubsection{Determination of organic carbon content of amaranth}

Whole amaranth plants were collected and dried overnight at $105^{\circ} \mathrm{C}$. The dry weight was then measured. The

Table 1 The different amounts of the two types of fertilizers added to each device

\begin{tabular}{lllll}
\hline \multirow{2}{*}{ Number } & \multicolumn{2}{l}{ Composition } & \multirow{2}{*}{ Abbreviation } \\
\cline { 2 - 4 } & Soil $(\mathrm{g})$ & MOF $(\mathrm{g})$ & CF $(\mathrm{g})$ & \\
\hline 1 & 2000 & - & - & WF \\
2 & 2000 & - & 7.475 & CF \\
3 & 2000 & 12.5 & - & $12.5 \mathrm{~F}$ \\
4 & 2000 & 25 & - & $25 \mathrm{~F}$ \\
5 & 2000 & 37.5 & - & $37.5 \mathrm{~F}$ \\
6 & 2000 & 50 & - & $50 \mathrm{~F}$ \\
\hline
\end{tabular}


percentage of carbon present was measured using an elemental analyzer (ElementarVario MACRO, Germany).

\subsubsection{Determination of soil parameters}

At the end of the experiment, soil moisture, $\mathrm{pH}$, and urease activity were tested. Portions of the naturally air-dried soil samples were used to determine SOC and microbial biomass.

To measure soil moisture content, an aliquot of moist soil (about $5 \mathrm{~g}$ ) was dried at $105{ }^{\circ} \mathrm{C}$. After $5 \mathrm{~h}$, the sample was placed in a desiccator to cool for $30 \mathrm{~min}$. Samples were dried and weighed repeatedly until the weight no longer decreased. $\mathrm{pH}$ was determined according to Fierer and Jackson (2006). Dry soil sample was mixed with water at a ratio of $1: 1$, then samples were shaken for $15 \mathrm{~min}$, left to settle for $30 \mathrm{~min}$, and tested with a $\mathrm{pH}$-meter.

Urease activity was test using colorimetric determination of ammonium (Kandeler and Gerber 1998). For this test, toluene $(1 \mathrm{ml})$ was mixed with $5 \mathrm{~g}$ natural air-dried soil sample for $15 \mathrm{~min}$. Then, urea solution $(10 \mathrm{ml}, 5 \%)$ and citrate buffer $(20 \mathrm{ml}, 0.96 \mathrm{M}, \mathrm{pH} 6.7)$ were added. Meanwhile, as a control, a repeat experiment was performed using an equal volume of distilled water instead of the urea solution. After incubation for $24 \mathrm{~h}$ at $37^{\circ} \mathrm{C}$, the solution was centrifuged $(4000 \mathrm{~g}, 10 \mathrm{~min})$. Supernatant $(1 \mathrm{ml})$ was mixed with sodium phenoxide solution $(4 \mathrm{ml}$, $2.7 \mathrm{M})$ and sodium hypochlorite solution $(3 \mathrm{ml}, 0.9 \%)$ in a $50 \mathrm{ml}$ volumetric flask. After $20 \mathrm{~min}$, the reaction solution was diluted to $50 \mathrm{ml}$ and the absorbance was measured at $460 \mathrm{~nm}$. Urease activity was expressed according to the milligrams of $\mathrm{NH}_{3}-\mathrm{N}$ in $1 \mathrm{~g}$ soil.

SOC determination was followed by a previous report (Page 1982), dry soil (2 g) was added to $\mathrm{HCl}$ solution (40 ml, 5\%), and the mixture blended for $10 \mathrm{~min}$. The tubes were then spun at $8000 \mathrm{~g}$ for $5 \mathrm{~min}$. After this, the samples were rinsed 3 times with ultrapure water. After drying at $105{ }^{\circ} \mathrm{C}$, the residual solids were weighed and the carbon content tested using the elemental analyzer (ElementarVario MACRO, Germany).

The microbial biomass in the soil was measured using the method outlined by Vance et al. (1987) involving chloroform-fumigation and extraction. Moist soil was fumigated in a sealed desiccator using ethanol-free chloroform for $24 \mathrm{~h}$ at $25^{\circ} \mathrm{C}$. Water $(20 \mathrm{ml})$ and the same amount of $\mathrm{NaOH}$ $(1 \mathrm{M})$ were placed in the bottom to trap any evolved $\mathrm{CO}_{2}$. Non-fumigated soil was used as a control. Fumigated and non-fumigated soils were subjected to extraction using $0.5 \mathrm{M} \mathrm{K}_{2} \mathrm{SO}_{4}$ solution for 30 min using an 'end-over-end' shaker at $350 \mathrm{rpm}$. After centrifugation, supernatant was filtered through a $0.45 \mu \mathrm{m}$ membrane. The filtrate was tested using a total organic carbon analyzer (Shimadzu TOCVCSN, Japan). The soil microbial biomass carbon $\left(\mathrm{B}_{\mathrm{C}}\right)$ was estimated from $\mathrm{Bc}=\mathrm{Ec} / \mathrm{k}_{\mathrm{EC}}$, where $\mathrm{Ec}=$ [organic carbon extracted by $\mathrm{K}_{2} \mathrm{SO}_{4}$ from fumigated soil-carbon extracted by $\mathrm{K}_{2} \mathrm{SO}_{4}$ from non-fumigated soil] ( $\mathrm{Wu}$ et al. 1990). The quantity $\mathrm{k}_{\mathrm{EC}}$ (the proportion of the extracted microbial biomass carbon evolved as organic carbon)was taken to be 0.45 following the work of Wu et al. (1990).

To test available potassium content, a portion $(0.5 \mathrm{~g})$ of crushed dry sample (50-80 mesh) and ammonium acetate solution $(50 \mathrm{ml}, 1 \mathrm{M})$ were mixed in an extraction bottle (flask) following the method of Zhu et al. (2013). Then, the bottle was stoppered and oscillated for $30 \mathrm{~min}$. The mixture was filtered using a filter paper, and the filtrate collected for testing using a full-spectrum, direct-reading plasma emission spectrometer (Thermo Fisher Scientific, UK).

\subsubsection{Determination of SIW parameters}

$\mathrm{pH}$ and temperature of the SIW was measured using a $\mathrm{pH}$ meter (S20 SevenEasy, Mettler-Toledo). The concentrations of certain cations $\left(\mathrm{K}^{+}, \mathrm{Na}^{+}, \mathrm{Ca}^{2+}\right.$, and $\left.\mathrm{Mg}^{2+}\right)$ were determined using an atomic absorption analyzer (AA900F, PerkinElmer, US). Anion concentrations $\left(\mathrm{Cl}^{-}\right.$and $\left.\mathrm{SO}_{4}{ }^{2-}\right)$ were determined using ion chromatography (DIONEX ICS-90, US). An acid-base titration method was used to measure the content of the bicarbonate in the aqueous solution according to the published literature with a little modification (Verma 2004). The SIW was filtered using a $0.45 \mu \mathrm{m}$ microporous membrane and $20 \mathrm{ml}$ titrated with a standardized $\mathrm{HCl}$ solution. The above parameters $(\mathrm{pH}$, water temperature, ion concentrations) were imported into appropriate software (MINTEQ) to calculate the saturation index of the calcite.

\subsection{Statistical analysis}

STATISTICA 6.0 software was used to analyze the data. The significance of the differences between the treatments was tested separately using one-way ANOVA tests followed by Fisher LSD tests for mean comparisons. The data were shown in the form of average value of at least three independent experiments. The standard deviation was presented as well.

\section{Results}

\subsection{Carbon content of Amaranth}

For the average carbon content, $\mathrm{CF}$ and MOF were both conducive to amaranth growth (see Fig. 1). Those fertilizers thus improved organic carbon fixation. With the increase of MOF applied, carbon content of amaranth raised. From a statistical point of view, only adding $50 \mathrm{~g}$ 


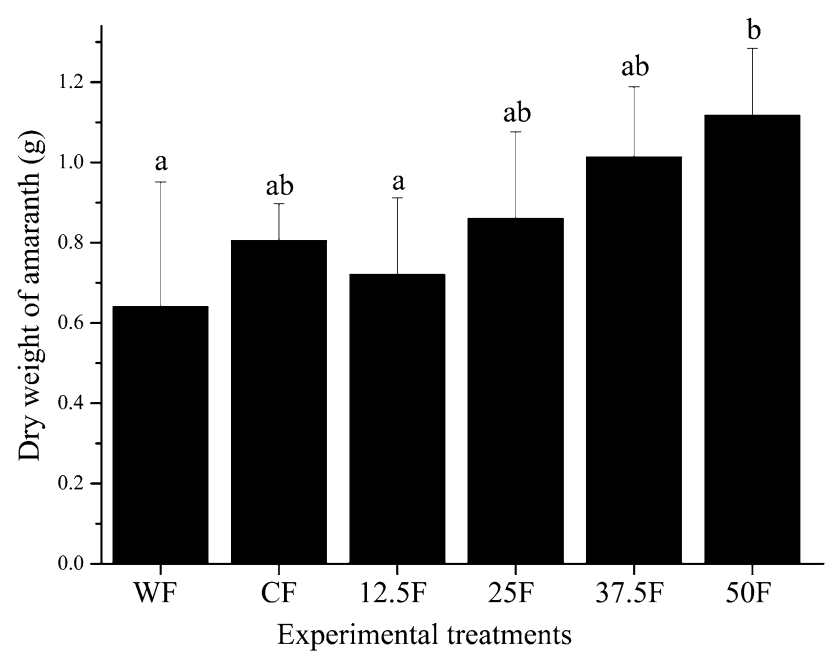

Fig. 1 Amaranth carbon content with application of different fertilizers

MOF (50F) was beneficial to the promotion of organic carbon content. Anyhow, it was enough to prove that application of MOF was more conducive to the growth of amaranth than $\mathrm{CF}$ under the premise of consistent usage amount of $\mathrm{N}, \mathrm{P}$, and $\mathrm{K}$.

\subsection{Soil parameters}

Soil moisture content was not significantly different (statistically) among the five different kinds of treatment (ranging from $11.6 \%$ to $16.8 \%$ ). MOF significantly increased soil pH in all four treatments (Fig. 2a). Different addition amounts of MOF did not result in the difference of soil $\mathrm{pH}$, except for the $50 \mathrm{~F}$ treatment. The maximum amount of MOF added gave rise to the highest $\mathrm{pH}$ value. On the contrary, the addition of $\mathrm{CF}$ made the $\mathrm{pH}$ value decrease obviously (Fig. 2a).

As can be seen from Fig. $2 b$, the addition of CF and a relatively minor amount of MOF $(12.5 \mathrm{~F})$ did not contribute to the accumulation of soil organic carbon. Nonetheless, it was significantly boosted after adding a large amount of MOF (25F, 37.5F, and 50F). Compared 37.5F with 50F, it suggested that adding too much MOF did not increase SOC content, i.e. $37.5 \mathrm{~g}$ MOF had made the content of SOC reach a high level.

The application of $\mathrm{CF}$ did not cause the change of microbial biomass (Fig. 2c). Obviously, MOF was benefited to microbial reproduction and growth. Compared to WF treatment, it increased fourfolds after adding $37.5 \mathrm{~g}$ MOF. Regardless of $50 \mathrm{~F}$, it showed that some positive correlation between microbial biomass and the amount of MOF. To our surprise, adding $50 \mathrm{~g}$ MOF caused the soil microbial biomass to decline a certain amount, but it was still notably higher than WF and CF treatments. Excess MOF was against to microbial proliferation and had a dilution effect on the ratio of microbial biomass in soil. It indicated that appropriate implement of MOF had greatest benefits to microbial biomass and plant production.

Urease activity nearly doubled after the addition of $\mathrm{CF}$ (Fig. 2d). For the impact of MOF on urease activity, although there was no difference between $25 \mathrm{~F}$ and $37.5 \mathrm{~F}$, the result implied that MOF can improve urease activity significantly.

The results of application of fertilizer on available potassium were very similar with the trend of $\mathrm{pH}$. $\mathrm{CF}$ did not provide much available potassium. MOF had an ability to release potassium ion according to Fig. 2e, except that there was no statistical difference between $\mathrm{WF}$ and $37.5 \mathrm{~F}$. However, excessive addition of MOF did not significantly increase the available potassium content.

\subsection{SIW parameters}

\section{$3.3 .1 \mathrm{pH}$}

Both CF and MOF significantly affected $\mathrm{pH}$ of SIW (Fig. 3a). Nevertheless, the effects were distinctly different. $\mathrm{CF}$ promoted an obvious decrease in $\mathrm{pH}$ value, which was always lower than 7.0 throughout the course of the experiment. The amount of MOF added affected $\mathrm{pH}$ value significantly at the first stage of this experiment. The $\mathrm{pH}$ value of SIW increased when more MOF was added, and it was alkaline in the presence of MOF.

\subsubsection{The concentration of $\mathrm{HCO}_{3}{ }^{-}$}

Application of MOF had a great effect on $\mathrm{HCO}_{3}^{-}$concentration (Fig. 3b). Similar to $\mathrm{pH}$, the application of $\mathrm{CF}$ made $\mathrm{HCO}_{3}{ }^{-}$concentration reduce clearly, i.e. the concentrations of $\mathrm{HCO}_{3}{ }^{-}$in the groups treated by MOF were much higher than those in the groups of $\mathrm{CF}$ and $\mathrm{WF}$. Adding more $\mathrm{MOF}$ caused more $\mathrm{HCO}_{3}{ }^{-}$producing.

\subsection{3 $\mathrm{K}^{+}$concentration}

$\mathrm{K}^{+}$concentration of the application of $\mathrm{CF}$ was highest during the whole experimental process (Fig. 3c). Overall, the $\mathrm{K}^{+}$concentration was positive correlation to the amount of added MOF. Minimum addition of MOF (12.5F) did not seem to provide an extra $\mathrm{K}^{+}$(see Fig. 3c). However, others treatments $(25 \mathrm{~F}, 37.5 \mathrm{~F}$, and $50 \mathrm{~F})$ had an ability to release relative more amounts of $\mathrm{K}^{+}$. The average $\mathrm{K}^{+}$ concentration in the $25 \mathrm{~F}, 37.5 \mathrm{~F}$, and $50 \mathrm{~F}$ treatments always exceeded that in WF.

\subsubsection{Saturation index calculation}

MINTEQ software was used to calculate the saturation index of calcite (SIC) using the following parameters: 

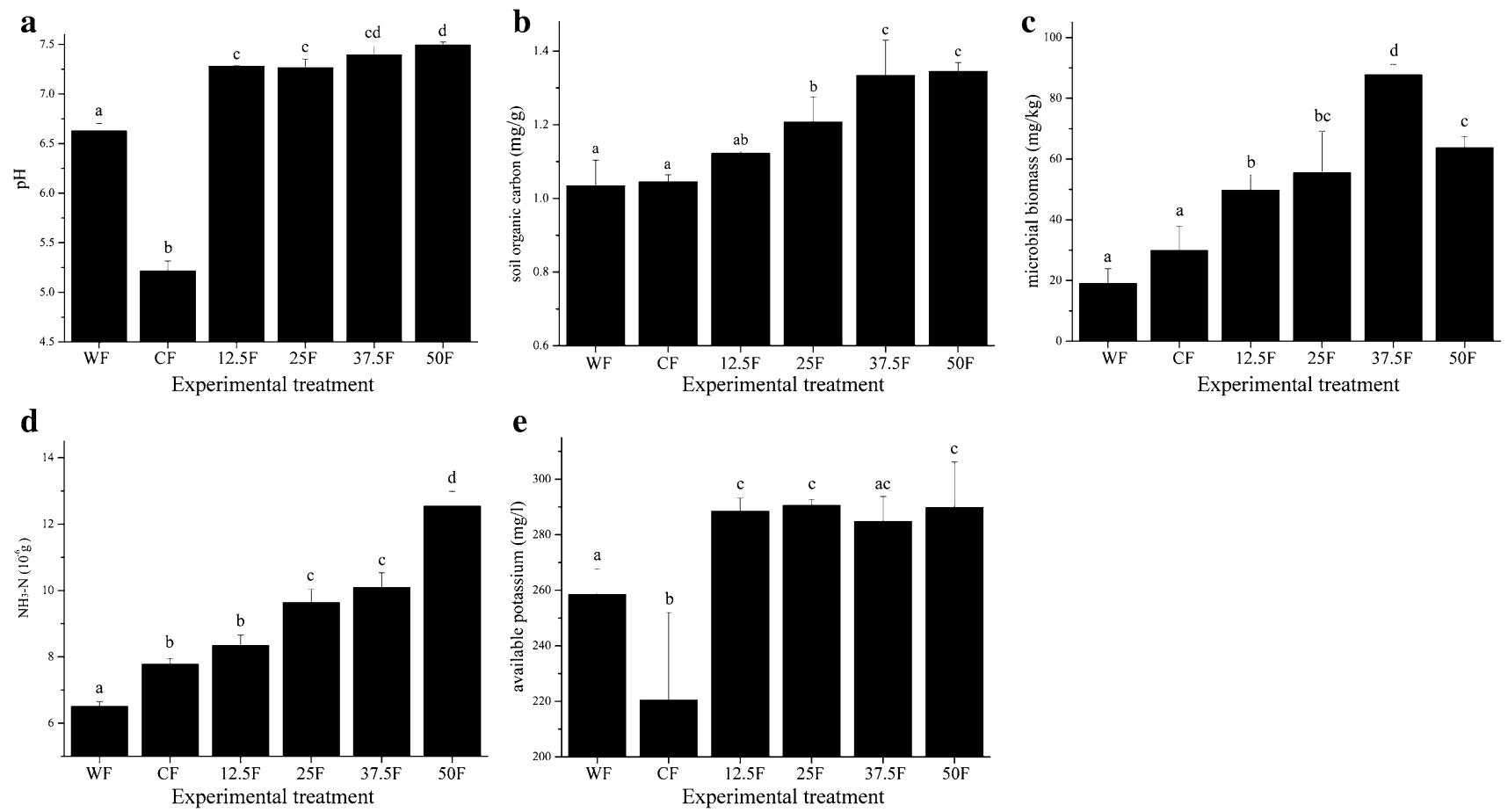

Fig. 2 The effect of addition of $\mathrm{CF}$ and MOF into soil on multiple soil parameters. a, b, c, $\mathbf{d}$ and e represent soil pH, soil organic carbon, microbial biomass, urease and available potassium, respectively

water temperature, $\mathrm{pH}$, and the concentrations of $\mathrm{K}^{+}, \mathrm{Na}^{+}$, $\mathrm{Ca}^{2+}, \mathrm{Mg}^{2+}, \mathrm{Cl}^{-}, \mathrm{SO}_{4}{ }^{2-}$, and $\mathrm{HCO}_{3}{ }^{-}$ions. The application of CF made SIC decrease obviously (Fig. 3d). Overall, compared with WF, the addition of MOF can increase SIC. MOF was benefited to form saturation state of calcite.

\section{Discussion}

Excessive application of $\mathrm{CF}$ caused soil acidification. Here, our results showed that both soil and SIW pH decreased sharply with the addition of CF. Clearly, it was the nonnegligible stain for agriculture practice. Conversely, MOF was an environmentally friendly fertilizer, which can even mitigate the effect of acid rain (Allen and Brent 2010) and/ or improve soil that has been acidified. Su et al. (2006) studied long-term effect of fertilizer and manure application on soil-carbon sequestration and soil fertility under the wheat-wheat-maize cropping system in northwest China. The results showed that application of inorganic fertilizer alone did not increase SOC concentrations compared with no application of fertilizers. Our finding that there was no difference between WF and CF on SOC (Fig. 2b) was consistent with above report. The MOF fertilizer indeed increased the content of SOC significantly. Our results showed that urease activity was significantly affected by different fertilization regimes. Specially, the activity of urease was positive correlation with the usage amount of
MOF. It was noticed that urease activity had a positive correlation with organic carbon and total nitrogen (Zantua et al. 1977). So soil biogeochemical cycles, especially carbon and nitrogen cycles, was improved by MOF accordingly. Clearly, CF can not provide potassium persistently (Fig. 2e). In contrast, the content of available potassium was significantly increased after the adding of MOF. It implies that this kind of fertilizer style is favorable for long-term supply of potassium. Potassium is one of the most abundant cation in plants, comprising up to $10 \%$ of a plant's dry weight (Leigh and Wynjones, 1984). The application of MOF is an undoubtedly attemptable way to improve soil potassium content to alleviate the lack of soluble potassium. It can avoided to overuse CF. The content of $\mathrm{N}, \mathrm{P}$, and $\mathrm{K}$ in $50 \mathrm{~g} \mathrm{MOF}$ was equal to that in $7.476 \mathrm{~g} \mathrm{CF}$. For all soil parameters measured (Fig. 2), most importance of all, the addition of $25 \mathrm{~g}$ MOF was more significant than $7.476 \mathrm{~g} \mathrm{CF}$ for improving soil quality.

From the potential effect of application of MOF on carbon fixation, previous research showed that secondary carbonate preferred to accumulate in $\mathrm{pH}$ range of 7.3-8.5 (Lal 2008). Our results here demonstrated that soil $\mathrm{pH}$ was just in this interval when MOF was used. Carbonate mineral precipitation was controlled by the saturation state of the soil solution and depended on activities of dissolved species (cation and (bi)carbonate). $\mathrm{HCO}_{3}{ }^{-}$ concentrations were positive correlation to the amount of MOF used (Fig. 3b). The more positive SIC meant that 

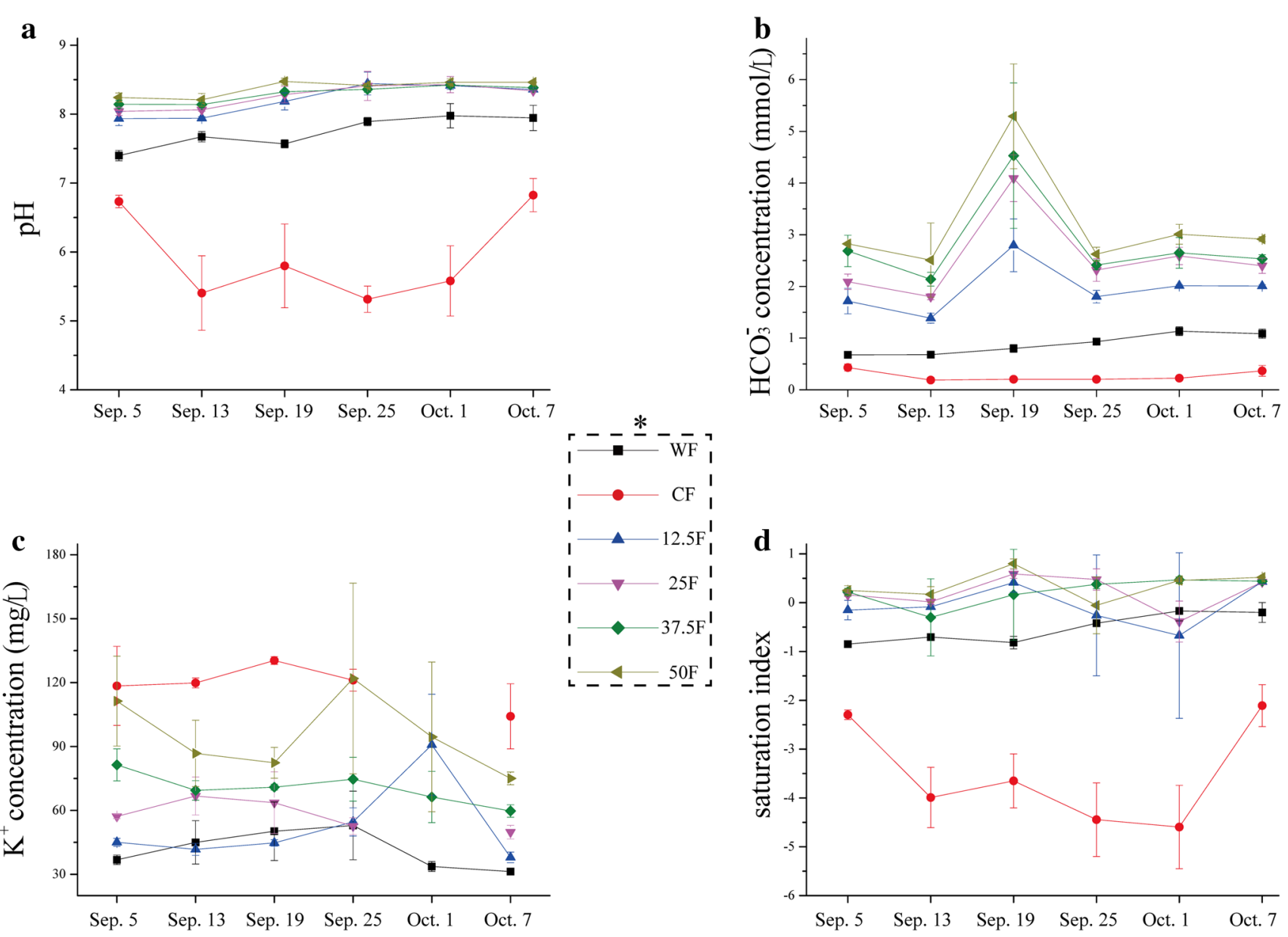

Fig. 3 The effect of addition of $\mathrm{CF}$ and MOF into soil on multiple soil filtrate parameters. a, b, $\mathbf{c}$ and $\mathbf{d}$ represent $\mathrm{pH}, \mathrm{HCO}_{3}{ }^{-}$concentration, $\mathrm{K}^{+}$ concentration and calcite saturation index, respectively

these $\mathrm{HCO}_{3}^{-}$was easier to form a stable form of solid carbon, e.g. $\mathrm{CaCO}_{3}$. Our recent study also suggests tha$\mathrm{t}$ adding dolomite and $\mathrm{K}$-feldspar into soil is a feasible way to increase carbon sequestration (Xiao et al. 2016). In view of this, the application of MOF may be significant for accelerating atmospheric $\mathrm{CO}_{2}$ sequestration and/or slowing down soil $\mathrm{CO}_{2}$ emission.

\section{Conclusion}

The application of MOF not only improved plant growth and some indicators of soil quality, e.g. SOC content, microbial biomass, available potassium but also provided a possible method of accelerating carbon fixation. Despite the limitations of the work presented here, it still showed a promising way to improve soil quality in the long-term sustainable natural farming.
Acknowledgements Funding was provided by the National Natural Science Foundation of China (Grant No. 41373078), the National Key Basic Research Program of China (Grant No. 2013CB956702), the Key Project of Natural Science Research in Colleges and Universities in Jiangsu Province (Grant No. 16KJA180003), and the Natural Science Foundation of Shandong Province (Grant No. ZR2016DQ12).

\section{References}

Allen DJ, Brent GF (2010) Sequestering $\mathrm{CO}_{2}$ by mineral carbonation: stability against acid rain exposure. Environ Sci Technol 44:2735-2739

Coutinho HLC, Noellemeyer E, de Carvalho-Balieiro F, Pineiro G, Fidalgo ECC, Martius C, da Silva CF (2015) Impacts of land-use change on carbon stocks and dynamics in central-southern South American biomes: Cerrado, Atlantic Forest and Southern Grasslands. Water Resour Manag 10(2):107-127

Dhadli HS, Brar BS (2016) Effect of long-term differential application of inorganic fertilizers and manure on soil $\mathrm{CO}_{2}$ emissions. Plant Soil Environ 62(5):195-201

Fan JL, Ding WX, Xiang J, Qin SW, Zhang JB, Ziadi N (2014) Carbon sequestration in an intensively cultivated sandy loam soil 
in the North China Plain as affected by compost and inorganic fertilizer application. Geoderma 230:22-28

Fierer N, Jackson RB (2006) The diversity and biogeography of soil bacterial communities. Proc Natl Acad Sci USA 103:626-631

Kandeler E, Gerber H (1998) Short-term assay of soil urease activity using colorimetric determination of ammonium. Biol Fertil Soils 6:68-72

Kang Y, Hao Y, Shen M, Zhao Q, Li Q, Hu J (2016) Impacts of supplementing chemical fertilizers with organic fertilizers manufactured using pig manure as a substrate on the spread of tetracycline resistance genes in soil. Ecotoxicol Environ Saf 130:279-288

Lal R (2004a) Carbon sequestration in dry land ecosystems. Environ Manag 33:528-544

Lal R (2004b) Soil carbon sequestration to mitigate climate change. Geoderma 123:1-22

Lal R (2008) Sequestration of atmospheric $\mathrm{CO}_{2}$ in global carbon pools. Energy Environ Sci 1:86-100

Leigh RA, Wynjones RG (1984) A hypothesis relating critical potassium concentrations for growth to the distribution and functions of this ion in the plant cell. N Phytol 97:1-13

Li T, Ma G, Zhang X (2006) Root exudates of potassium-enrichment genotype grain amaranth and their activation on soil mineral potassium. J Appl Ecol 17:368-372

Liping G, Erda L (2001) Carbon sink in cropland soils and the emission of greenhouse gases from paddy soils: a review of work in China. Chemosphere Glob Chang Sci 3:413-418

Mahmoodabadi M, Heydarpour E (2014) Sequestration of organic carbon influenced by the application of straw residue and farmyard manure in two different soils. Int Agrophys 28:169-176

Metz B (2001) Climate change 2001 mitigation: contribution of Working Group III to the third assessment report of the Intergovernmental Panel on Climate Change. Cambridge University Press, Cambridge

Page AL (1982) Methods of soil analysis. Part 2. Chemical and microbiological properties. American Society of Agronomy Inc, Soil Science Society of America Inc, Madison

Renforth P, Manning DAC, Lopez-Capel E (2009) Carbonate precipitation in artificial soils as a sink for atmospheric carbon dioxide. Appl Geochem 24:1757-1764

Rochette P, Gregorich EG (1998) Dynamics of soil microbial biomass $\mathrm{C}$, soluble organic $\mathrm{C}$ and $\mathrm{CO}_{2}$ evolution after three years of manure application. Can J Soil Sci 78(2):283-290

Ryan PR, Delhaize E, Jones DL (2001) Function and mechanism of organic anion exudation from plant roots. Annu Rev Plant Physiol Plant Mol Biol 52:527-560

Schlesinger WH (1999) Carbon and agriculture: carbon sequestration in soils. Science $284: 2095$

Schuiling $\mathrm{R}$ (2014) Climate change and $\mathrm{CO}_{2}$ removal from the atmosphere. Nat Sci 6:659-663
Schuiling R, Andrade A (1999) Recovery of struvite from calf manure. Environ Technol 20:765-768

Su YZ, Wang F, Suo DR, Zhang ZH, Du MW (2006) Long-term effect of fertilizer and manure application on soil-carbon sequestration and soil fertility under the wheat-wheat-maize cropping system in northwest China. Nutr Cycl Agroecosyst 75:285-295

Sun L, Xiao L, Xiao B, Wang W, Pan C, Wang S, Lian B (2013) Differences in the gene expressive quantities of carbonic anhydrase and cysteine synthase in the weathering of potassium-bearing minerals by Aspergillusniger. Sci China Earth Sci $56: 2135-2140$

Triberti L, Nastri A, Giordani G, Comellini F, Baldoni G, Toderi G (2008) Can mineral and organic fertilization help sequestrate carbon dioxide in cropland? Eur J Agron 29:13-20

Vance E, Brookes P, Jenkinson D (1987) An extraction method for measuring soil microbial biomass C. Soil Biol Biochem 19:703-707

Verma MP (2004) A revised analytical method for $\mathrm{HCO}_{3}{ }^{-}$and $\mathrm{CO}_{3}{ }^{2-}$ determinations in geothermal waters: an assessment of IAGC and IAEA interlaboratory comparisons. Geostand Geoanal Res 28:391-409

Wu J, Joergensen R, Pommerening B, Chaussod R, Brookes P (1990) Measurement of soil microbial biomass $\mathrm{C}$ by fumigationextraction-an automated procedure. Soil Biol Biochem 22:1167-1169

Xiao L, Hao J, Wang W, Lian B, Shang G, Yang Y, Wang S (2014) The up-regulation of carbonic anhydrase genes of Bacillus mucilaginosus under soluble $\mathrm{Ca}^{2+}$ deficiency and the heterologously expressed enzyme promotes calcite dissolution. Geomicrobiol J 31:632-641

Xiao L, Lian B, Hao J, Liu C, Wang S (2015) Effect of carbonic anhydrase on silicate weathering and carbonate formation at present day $\mathrm{CO}_{2}$ concentrations compared to primordial values. Sci Rep 5:7733. doi:10.1038/srep07733

Xiao LL, Sun QB, Li XX, Chu Y, Yuan HT, Ruan YL, Lu CM, Lian B (2016) A feasible way to increase carbon sequestration by adding dolomite and K-feldspar to soil. Cogent Geosci 2:1205324

Xie JC (1998) Present situation and prospects for the world's fertilizer use. Plant Nutr Fertil Sci 4:321-330

Young LM (2003) Carbon sequestration in agriculture: the US policy context. Am J Agric Econ 85:1164-1170

Zantua MI, Dumenil LC, Bremner JM (1977) Relationships between soil urease activity and other soil properties. Soil Sci Soc Am J 41:350-352

Zhu X, Lian B, Yang X, Liu C, Zhu L (2013) Biotransformation of earthworm activity on potassium-bearing mineral powder. J Earth Sci 24:65-74 